\title{
ANALISIS PENGENDALIAN KUALITAS PERSENTASE KADAR AIR PRODUK WAFER STICK PADA INDUSTRI MAKANAN RINGAN
}

\author{
Debrina Puspita Andriani ${ }^{1)}$, Ahmad Kanzul Fikri ${ }^{2)}$, Shintya Dwi Nur'aini ${ }^{3)}$ \\ ${ }^{1,2,3}$ Teknik Industri, Fakultas Teknik, Universitas Brawijaya
}

\begin{abstract}
Abstrak. Salah satu produk yang diproduksi oleh perusahaan studi kasus, yaitu produk wafer stick, diketahui memiliki presentase kadar air di atas standar perusahaan. Keadaan tersebut menimbulkan berbagai macam defect diantaranya melempem, rapuh, stik jembret, dan lain sebagainya. Sehubungan dengan semakin meningkatnya permintaan terhadap produk tersebut di pasaran, perusahaan ingin berupaya untuk mengurangi defect yang terjadi dengan menjaga jumlah produk yang berkualitas baik. Metode grafik peta kendali rata-rata $(\mathrm{X})$ dan jarak (R) dilakukan untuk mengevaluasi apakah suatu proses baking produk wafer stick telah berada dalam pengendalian kualitas secara statistika atau tidak. Apabila proses sudah berada didalam batas pengendalian yang ditentukan, maka dilakukan analisis kapabilitas proses untuk mengetahui apakah proses masih capable dan menghasilkan produk sesuai dengan spesifikasi. Pada tahap akhir penelitian dilakukan analisis penyebab kadar air yang menyebabkan produk wafer stick tidak memenuhi standar dengan diagram sebab-akibat atau fishbone diagram. Dengan analisis tersebut selanjutnya dapat dirumuskan rekomendasi perbaikan kepada perusahaan agar dapat menghasilkan produk yang berkualitas dan sesuai dengan spesifikasi pelanggan.
\end{abstract}

Kata Kunci: Analisis Kemampuan Proses, Fishbone Diagram, Pengendalian Kualitas, Peta Kendali,, Wafer Stick.

\section{PENDAHULUAN}

Wafer stick merupakan salah satu produk yang tergolong dalam jenis biskuit yang diproduksi perusahaan studi kasus yang bergerak di bidang industri makanan ringan. Berdasarkan data perusahaan dalam setahun terakhir, produk tersebut memiliki permintaan pasar yang semakin tinggi, sehingga proses produksi yang dilakukan diharapkan dapat menghasilkan produk yang nantinya dapat diterima oleh masyarakat. Untuk mencapai hal tersebut, maka diperlukan inspeksi mulai dari datangnya bahan baku, proses produksi, hingga produk siap dikirim ke distributor. Saat kedatangan bahan baku, perusahaan melakukan inspeksi apakah bahan baku sudah sesuai standar atau tidak. Pada proses produksi dan pengiriman juga dilakukan inspeksi atau quality control untuk tiap tahapnya.

Quality control atau pengendalian kualitas adalah kegiatan terpadu mulai dari pengendalian standar kualitas bahan, standar proses produksi, sampai standar pengiriman produk akhir ke konsumen, agar barang atau jasa yang dihasilkan sesuai dengan spesifikasi kualitas yang direncanakan [1]. Pada pelaksanaan pengendalian kualitas, produk diperiksa berdasarkan standar yang ditetapkan dan apabila terdapat penyimpangan atau perbedaan dengan standar, hal tersebut akan digunakan sebagai umpan balik sehingga dapat dilakukan tindakan perbaikan produksi untuk masa yang akan datang [2]. Quality control di perusahaan selama ini dilakukan dengan memeriksa kualitas wafer stick setelah proses baking, pemeriksaan kemasan setelah packaging, pemeriksaan produk pada pallet, dan pemeriksaan status "terima" pada produk akhir.

Berdasarkan hasil observasi dan wawancara pada proses quality control setelah proses baking, diperoleh faktorfaktor yang mempengaruhi defect pada produk wafer stick. Pada Gambar 1 diketahui bahwa penyebab cacat tertinggi produk terletak pada parameter kadar air (45\%). Parameter kadar air yang ditentukan oleh perusahaan maksimal 2\%. Kadar air pada produk yang tidak sesuai standar dapat mengakibatkan berbagai macam defect, diantaranya melempem, rapuh, jembret, dan lainnya. Melihat kondisi pasar, permintaan dari produk produk wafer stick juga semakin menigkat, sehingga pihak perusahaan ingin lebih memaksimalkan proses produksi produk wafer stick dengan meningkatkan kualitas produk terutama dalam mengurangi defect yang disebabkan kadar air yang tidak 
sesuai dengan standar.

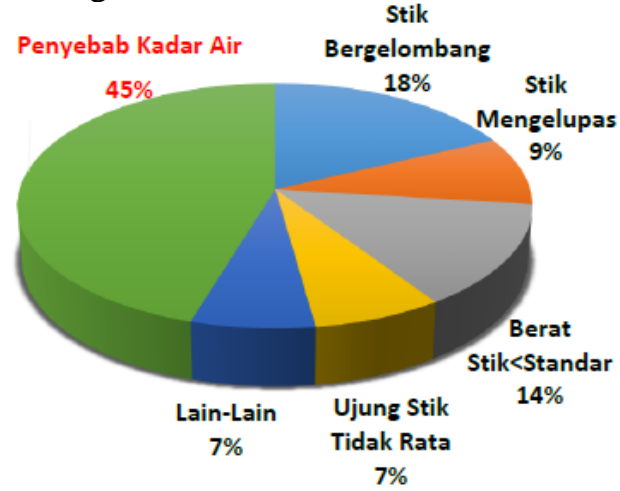

Gambar 1. Presentase Faktor Defect Wafer Stick

Penelitian ini dilakukan untuk mengetahui kualitas produk wafer stick berdasarkan kandungan kadar air, mengetahui penyebab standar mutu kandungan kadar air berada diatas batas spesifikasi yang ditentukan perusahaan, serta memberikan rekomendasi perusahaan dalam meningkatkan kualitas produk dengan faktor kandungan kadar air pada produk.

\section{Pengendalian Kualitas}

Pengendalian kualitas adalah aktivitas keteknikan dan manajemen, yang dengan aktivitas itu kita ukur ciri-ciri kualitas produk membandingkannya dengan spesifikasi atau persyaratan, dan mengambil tindakan penyehatan yang sesuai apabila ada perbedaan anatara penampilan yang sebenarnya dan yang standar [3]. Tujuan pengendalian kualitas menurut antara lain hasil produksi sesuai standar yang ditetapkan, agar bisa menyesuaikan biaya inspeksi menjadi sekecil mungkin, biaya desain produk dan proses menggunakan mutu tertentu dapat menjadi kecil dan biaya produksi serendah mungkin [4].

Pengendalian kualitas statistik adalah suatu sistem yang dikembangkan untuk menjaga standar yang uniform dari kualitas hasil produksi, pada tingkat biaya yang minimum dan merupakan bantuan untuk mencapai efisiensi perusahaan dengan menggunakan metode statistik dalam pengumpulan data dan analisanya untuk menentukan dan mengawasi kualitas hasil produksi [5]. Tujuan utama dalam Statistical Process Control (SPC) adalah untuk meminimalkan variabilitas, memperbaiki kualitas produk, menjaga kestabilan proses, serta dapat mendeteksi adanya penyebab variasi khusus atau kesalahan proses melalui analisis data dari masa lalu maupun masa mendatang [6].

\section{Peta Kendali X dan R}

Peta kendali merupakan teknik yang dikenal sebagai metode grafik yang digunakan untuk mengevaluasi apakah suatu proses berada dalam pengendalian kualitas secara statistika atau tidak sehingga dapat memecahkan masalah dan menghasilkan perbaikan kualitas [7]. Berdasarkan jenis data, peta kendali dapat dibedakan menjadi peta kendali data atribut dan data variabel. Peta kendali X dan $\mathrm{R}$ merupakan salah satu metode peta kendali data variabel yang digunakan untuk pengukuran produk yang memiliki karakteristik kualitas yang dapat diukur secara kuantitatif [8]. Seperti berat, ketebalan, panjang, volume dan diameter. Peta kendali data variabel biasanya digunakan untuk pengendalian proses yang didominasi oleh mesin atau alat ukur [9].

Peta kendali memiliki prinsip yaitu mempunyai garis tengah (Central Line) atau biasa dinotasikan dengan CL. Sepasang batas kendali atas (UCL/Upper Control Limit) dan batas kendali bawah (LCL/Lower Control Limit) [10]. Selain itu, peta kendali juga memiliki sebaran nilai-nilai karakteristik kualitas yang menggambarkan keadaan dalam suatu proses. Dalam praktiknya, biasanya mendapatkan data mentah atau belum diolah dimana tidak diketahui rata-rata dan standar deviasi populasi. Maka dari itu, pengambilan sampel atau subgrup dilakukan untuk mengetahui apakah proses tersebut berada dalam kendali atau tidak. Rata-rata setiap sampel merupakan penjumlahan seluruh ukuran sampel dibagi dengan jumlah subsampel yang diambil per observasi. Formulasi rata-rata ditunjukkan pada Persamaan (1).

$$
\bar{x}=\frac{\bar{x}_{1}+\bar{x}_{2}+\cdots+x_{m}}{m}
$$

Range atau jarak adalah hasil pengurangan dari data subsampel terbesar dengan data subsampel terkecil. Selanjutnya rentang seluruh observasi dilakukan perhitungan rata-ratanya. Formulasi menentukan jarak berada pada Persamaan (2).

$$
\bar{R}=\frac{R_{1}+R_{2}+\cdots+R_{m}}{m}
$$

Formula untuk menghitung batas bawah dan 
batas atas kendali statistik dirumuskan pada Persamaan (3) hingga (5) untuk Peta Kendali X dan Persamaan (6) hingga (7) untuk Peta Kendali R.

$$
\begin{aligned}
& U C L=x b a r+A_{2} * \text { Rbar } \\
& C L=x b a r \\
& L C L=x b a r-A_{2} * \text { Rbar } \\
& U C L=D_{4} * \text { Rbar } \\
& C L=R \text { Rar } \\
& L C L=D_{3} * \text { Rbar }
\end{aligned}
$$

Dimana nilai A2 diketahui melalui tabel data variabel dengan keterangan jumlah subsampel, sedangkan nilai D4 dan D3 diketahui melalui tabel data variabel dengan keterangan jumlah subsampel [11].

\section{Analisis Kapabilitas Proses}

Kapabilitas proses merupakan suatu ukuran kinerja yang menunjukkan proses tersebut mampu menghasilkan sesuai dengan spesifikasi produk yang diterapkan oleh manajemen berdasarkan kebutuhan dan ekspektasi pelanggan [12]. Yang harus dipertimbangkan adalah proses produksi berada dalam batas pengendalian tetapi produk tidak memenuhi spesifikasi atau proses produksi berada diluar batas pengendalian tetapi produk memenuhi spesifikasi. Tujuan dilakukannya analisis kemampuan proses adalah memprediksi variablitias proses yang ada, memilih diantara proses-proses yang paling tepat atau memenuhi toleransi menyediakan dasar kuantitatif untuk menyusun jadwal pengendalian proses dan penyesuaian secara periodik, menguji teori mengenai penyebab kesalahan selama program perbaikan kualitas, memberikan pelayanan sebagai dasar untuk menentukan syarat kinerja kualitas untuk mesin-mesin yang ada [13].

Pada proses yang berada pada kondisi in statistical control, cara membuat analisis kemampuan proses, antara lain:

1. Rasio kemampuan proses/ process capability ratio atau nilai $\mathrm{Cp}$

$$
\begin{aligned}
& R K P=\frac{U S L-L S L}{6 \sigma} \\
& \sigma=\frac{R b a r}{d 2}
\end{aligned}
$$

Dimana RKP adalah rasio kemampuan proses, USL adalah batas spesifikasi atas dan LSL adalah batas spesifikasi bawah yang ditetapkan konsumen dan harus dipenuhi oleh para produsen, serta $\sigma$ adalah standard deviasi proses. Dari hasil perhitungan tersebut, apabila nilai
RKP > 1 berarti proses masih baik (capable), RKP < 1 berarti proses tidak baik (not capable), dan RKP $=1$ berarti proses sama dengan spesifikasi konsumen. Semakin tinggi indeks kemampuan proses maka semakin sedikit produk yang berada di luar batas-batas spesifikasi.

2. Indeks Kemampuan Proses (Cpk)

Nilai indeks kemampuan proses akan mewakili kemampuan sesungguhnya dari suatu proses dengan parameter nilai tertentu. Nilai Cpk diformulasikan pada Pers. (11).

$$
C p k=\min \left\{\frac{U S L-\mu}{3 \sigma}, \frac{\mu-L S L}{3 \sigma}\right\}
$$

1)

$$
=\min \{C p u, C p l\}
$$

Dimana Cpu adalah indeks kemampuan atas sedangkan $\mathrm{Cpl}$ adalah indeks kemampuan bawah. Semakin tinggi indeks kemampuan proses maka semakin sedikit produk yang berada di luar batas-batas spesifikasi.

\section{Diagram Tulang Ikan}

Diagram sebab akibat disebut juga diagram tulang ikan atau Fishbone Chart. Diagram ini berguna untuk memperlihatkan faktor-faktor utama yang berpengaruh pada kualitas dan mempunyai akibat pada masalah yang dipelajari. Selain itu dapat melihat faktor-faktor yang lebih terperinci serta penyebab-penyebab dari faktor utama [14]. Diagram sebab akibat pertama kali dikembangkan oleh seorang pakar kualitas dari Jepang yaitu Dr. Kaoru Ishikawa pada tahun 1950 yang menggunakan uraian grafis dari unsur proses untuk menganalisa sumber-sumber potensial dari penyimpangan proses. Masalah utama yang diidentifikasi mencakup mesin, material, metode, pengukuran dan tenaga kerja [15].

\section{METODE}

Pengumpulan data pada penelitian ini diperoleh dari arsip atau dokumentasi data kadar air produk wafer stick sepanjang bulan Februari 2017. Terdapat 25 sampel yang diambil dengan 3 subsampel di tiap sampelnya. Subsampel yang dimaksud ialah 3 shift yaitu pukul $07.00 \mathrm{~s} / \mathrm{d} 15.00 \mathrm{WIB}$, pukul $15.00 \mathrm{~s} / \mathrm{d} 23.00 \mathrm{WIB}$, dan pukul 23.00 s/d 07.00 WIB. Penelitian ini juga mengambil data primer dengan melakukan wawancara secara langsung dengan operator 
dan karyawan di lini produksi tersebut. Selain itu juga dilakukan observasi untuk mengetahui keadaan sistem di perusahaan.

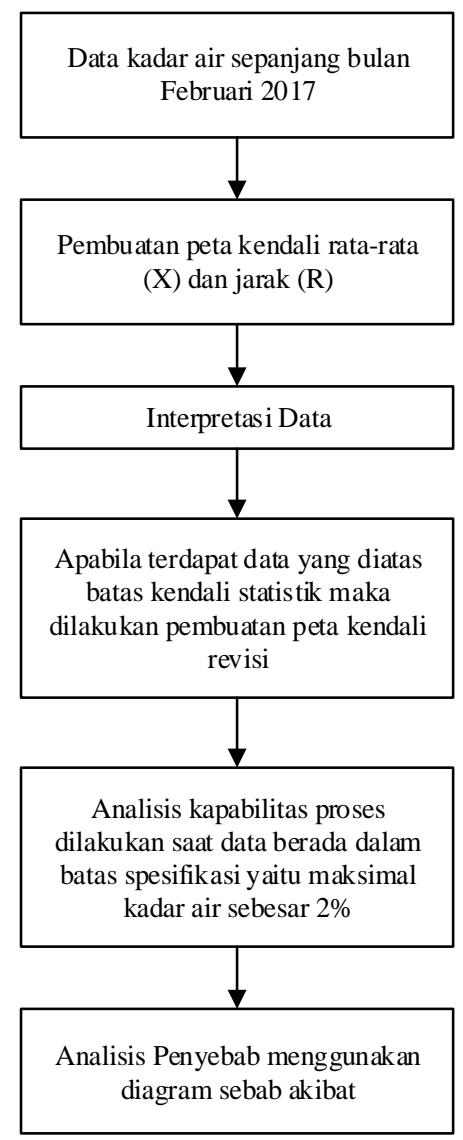

Gambar 2. Diagram Alir Penelitian

\section{HASIL DAN PEMBAHASAN}

Analisa pengendalian kualitas pada penelitian ini dimulai dengan mengukur kadar air produk wafer stick, selanjutnya menentukan nilai garis tengan (CL), batas kendali atas (UCL), dan batas kendali bawah (LCL). Dengan menggunakan peta kendali rata-rata $(\mathrm{X})$ dan peta kendali jarak (R) dapat mengetahui seberapa banyak data produk wafer stick yang berada dalam batas kendali statistik. Apabila terdapat data yang diluar batas kendali akan dilakukan penghilangan sampel terkait sehingga dibuat peta kendali revisi dimana keadaan data sudah berada dalam batas kendali.

Langkah berikutnya ialah melakukan analisis kemampuan proses untuk mengetahui kapabilitas dari proses tersebut. Langkah terakhir ialah menganalisis penyebab kandungan kadar air pada wafer stick yang tidak sesuai standar dengan menggunakan diagram tulang ikan (fishbone diagram). Pada Tabel 1 menunjukkan data pengukuran kadar air yang dikumpulkan selama penelitian dilakukan.

Tabel 1. Data Kadar Air

\begin{tabular}{|c|c|c|c|}
\hline \multirow{2}{*}{$\begin{array}{c}\text { Sampel } \\
\text { ke- }\end{array}$} & \multicolumn{3}{|c|}{ Rata-rata Kadar Air (\%) } \\
\cline { 2 - 4 } & Shift 1 & Shift 2 & Shift 3 \\
\hline 1 & 1,915 & 2,180 & 1,990 \\
2 & 1,695 & 1,930 & 1,930 \\
3 & 1,630 & 2,180 & 1,720 \\
4 & 1,695 & 1,890 & 1,145 \\
5 & 1,795 & 1,795 & 1,810 \\
6 & 1,745 & 1,790 & 1,155 \\
7 & 2,125 & 1,940 & 1,370 \\
8 & 1,830 & 1,770 & 1,985 \\
9 & 1,900 & 1,910 & 2,410 \\
10 & 1,815 & 1,850 & 1,675 \\
$:$ & & & \\
23 & 1,810 & 1,890 & 1,815 \\
24 & 1,915 & 1,875 & 1,905 \\
25 & 1,685 & 1,865 & 1,880 \\
\hline
\end{tabular}

Analisis dengan Peta Kendali Rata-rata (X) dan Jarak (R)

Untuk mengetahui kualitas produk, pada penelitian ini tidak dimungkinkan melakukan pemeriksaan terhadap setiap produk yang dihasilkan. Oleh karena itu, diperlukan sebuah pengkajian dengan metode statistik sehingga memudahkan dalam mengetahui kualitas produk secara menyeluruh dengan hanya mengambil beberapa sampel pada setiap shift yang dilakukan sebanyak 25 kali observasi selama Bulan Februari 2017. Metode statistik yang digunakan untuk menganalisis produk wafer stick ini adalah dengan menggunakan peta kendali rata-rata (X) dan jarak (R).

Langkah analisis yang pertama dilakukan dengan menggunakan peta kendali $\mathrm{X}$ dan $\mathrm{R}$ adalah perhitungan nilai garis tengah atau center line pada peta kendali rata-rata $(\mathrm{X})$ dengan Persamaan (1) dan diperoleh nilai sebesar 1,84 . Selanjutnya dilakukan perhitungan jarak pada setiap data dengan melakukan pengurangan data terbesar dengan data terkecil pada setiap sampel, kemudian dilakukan perhitungan garis tengah atau center line pula pada peta kendali jarak (R) dengan Persamaan (2) dan diperoleh nilai sebesar 0,3144. Setelah itu dilakukan perhitungan batas kendali atas dan bawah dengan Persamaan (3) dan (5) pada peta kendali rata-rata (X) kemudian didapatkan nilai masing-masing sebesar $2,16 \%$ dan $1,52 \%$. Selain itu juga dilakukan perhitungan batas kendali atas dan bawah dengan Persamaan (6) dan (8) pada peta kendali jarak (R) dan didapatkan nilai 
masing-masing sebesar 0,81 dan 0 .

Setelah mendapatkan nilai garis tengah, batas kendali atas, dan batas kendali bawah di atas, maka data yang telah dikumpulkan sebelumnya diplotkan dalam peta kendali ratarata $(\mathrm{X})$ dan jarak $(\mathrm{R})$. Pada Gambar 3 diketahui bahwa terdapat 1 data yang berada diluar batas kendali rata-rata, yaitu pada data ke-11, dimana persentase kandungan kadar air rata-rata pada sampel tersebut sebesar 2,185\% yang dengan demikian berada di atas batas kendali atas. Sebaliknya pada peta kendali jarak (R) tidak ditemukan data yang melebihi batas kendali, baik bawah maupun atas.

Selama ini, standar kandungan kadar air dalam wafer stick yang ditetapkan oleh perusahaan adalah maksimal sebesar $2 \%$, lebih kecil dibandingkan batas kendali atas pada peta kendali rata-rata $(\mathrm{X})$, yaitu $2,16 \%$. Berdasarkan kondisi tersebut dan brainstorming dengan pihak perusahaan dapat dianalisis bahwa penyebab data keluar dari batas kendali adalah karena penyebab khusus, yaitu adanya bagian dari kompresor yang kurang berfungsi sehingga pembuangan uap air tidak maksimal. Dengan mengatasi sebab khusus tersebut, data direvisi untuk diuji dengan peta kendali rata-rata $(\mathrm{X})$ dan jarak (R) kembali.

Dengan menghapus data ke-11, selanjutnya dilakukan perhitungan yang sama seperti sebelumnya, yaitu garis tengah, batas kendali atas dan batas kendali bawah pada peta kendali rata-rata $(\mathrm{X})$ dan jarak $(\mathrm{R})$. Dari langkah tersebut, untuk peta kendali rata-rata (X) didapatkan nilai garis tengah, batas kendali atas, dan batas kendali bawah masing-masing sebesar 1,8260; 2,1389; dan 1,5131. Sedangkan pada peta kendali jarak (R) didapatkan nilai garis tengah, batas kendali atas, dan batas kendali bawah masing-masing sebesar 0,3058; 0,7873 ; dan 0 . Setelah dilakukan revisi didapatkan hasil bahwa semua data sudah masuk kedalam batas pengendalian dan tidak ada data yang outlier. Peta kendali yang sudah direvisi dapat dilihat pada Gambar 4.

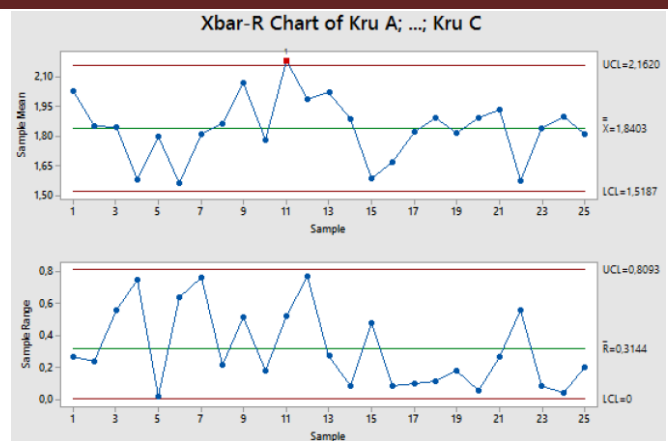

Gambar 3. Peta Kendali X dan R

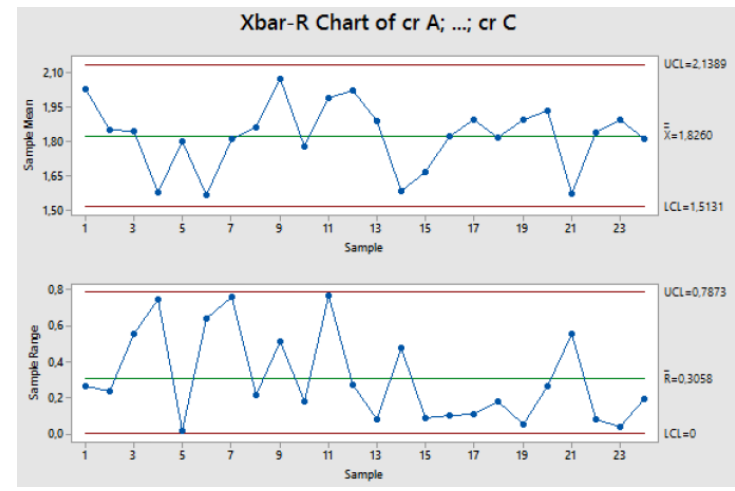

Gambar 4. Peta Kendali X dan R Revisi

\section{Analisis Kemampuan Proses (Cp)}

Standar yang ditetapkan oleh perusahaan untuk kandungan kadar air dalam produk wafer stick adalah sebesar $2 \%$, sehingga hal tersebut menjadi salah satu batas spesifikasi yang harus dipenuhi perusahaan mengenai mutu produknya. Dengan batas spesifikasi tersebut, selanjutnya dilakukan analisis apakah proses produksi yang dilakukan oleh perusahaan mampu/capable menghasilkan produk dalam batas spesifikasi dengan baik.

Langkah pertama yang dilakukan dalam analisis kemampuan proses yaitu dengan menghitung nilai $\sigma$ dengan Persamaan (10) sehingga didapatkan nilai 0,1857. Langkah selanjutnya yaitu menghitung rasio kemampuan proses (Cp) menggunakan Persamaan (9) dan didapatkan hasil sebesar 1,007. Kemudian setelah menghitung nilai $\mathrm{Cp}$, selanjutnya menghitung indeks kemampuan proses (Cpk) menggunakan Persamaan (11) dan didapatkan nilai sebesar 0,2872.

Berdasarkan perhitungan rasio kemampuan proses di atas dapat disimpulkan bahwa proses produksi wafer stick di perusahaan memiliki proses yang dianggap mampu untuk memenuhi spesifikasi yang dipersyaratkan, tetapi perlu 
pengendalian yang ketat karena nilai $\mathrm{Cp}$ mendekati 1. Sedangkan untuk nilai indeks kemampuan proses menunjukkan kapabilitas proses yang belum baik dan memungkinkan produk yang dihasilkan berada di luar batas spesifikasi. Selain itu, jika dilihat dari kecenderungan nilai $\mathrm{Cpk}$ dapat disimpulkan proses produksi belum mampu berada di tengah standar spesifikasi kandungan kadar air dan lebih cenderung menghasilkan produk di bawah standar.

Untuk mencapai visi perusahaan, yaitu menjadi perusahaan makanan dan minuman Indonesia terdepan, perusahaan berupaya untuk terus meningkatkan kualitas produk-produknya agar sesuai dengan standar yang telah ditetapkan. Oleh karena itu, menghadapi permasalahan ini perlu dilakukan analisis apakah proses yang ada saat ini masih mampu menghasilkan produk sesuai standar spesifikasi yang ditentukan oleh perusahaan atau perusahaan harus melakukan perbaikan yang lainnya.

\section{Analisis Faktor Penyebab dengan Fishbone Diagram}

Pada penelitian ini untuk mencari penyebab-penyebab cacat produk wafer stick digunakan diagram sebab akibat atau diagram tulang ikan (fishbone diagram) yang merupakan hasil wawancara dan diskusi dengan operator mesin, team leader produksi, kepala departemen dan staff dari departemen Quality Control perusahaan. Diagram ini digunakan untuk mencari sebab-sebab dari suatu penyimpangan. Dengan diagram ini akan dapat diketahui hubungan antara berbagai faktor meliputi manusia, mesin, material, metode, dan lingkungan yang menjadi penyebab terjadinya penyimpangan. Gambar 5 menunjukkan fishbone diagram untuk faktor-faktor penyebab cacat pada produk wafer stick dikarenakan parameter kandungan kadar air.

Terdapat 2 faktor utama yang berpengaruh besar dalam menentukan persentase kandungan kadar air produk wafer stick. Kedua faktor tersebut dianggap sebagai akar dari permasalahan utama penyebab cacat pada produk wafer stick dengan spesifikasi kandungan kadar air. Faktor tersebut adalah:

1. Kurangnya pengecekan dan perawatan pada kompresor

Terdapat 5 faktor utama pada permasalahan defect kadar air produk wafer stick, salah satunya yaitu faktor mesin. Pada mesin baking terdapat kompresor untuk membuang uap sisa pemanggangan adonan. Apabila kompresor tidak bekerja normal maka pembuangan uap air dapat terhambat sehingga menyebabkan kulit produk memiliki kadar air yang berlebih sehingga menimbulkan defect produk. Akar dari permasalahan tersebut yaitu berasal dari kurangnya pengecekan dan maintenance pada kompresor. Biasanya maintenance hanya dilakukan pada mesin baking sedangkan pada kompresor jarang dilakukan pengecekan oleh sebab itu terjadi penurunan kinerja. Dampaknya kadar air produk wafer stick akan tinggi.

2. Preventif maintenance tidak berjalan sesuai jadwal.

Faktor utama kedua yang berpengaruh pada kadar air produk wafer stick yaitu faktor metode. Walaupun faktor-faktor lain terpenuhi tetapi dalam metode pelaksanaannya tidak tepat, maka hasil yang didapatkan juga tidak akan sesuai harapan. Berdasarkan wawancara kepada supervisor produksi, diketahui pengaturan pengapian mesin baking tidak optimal dikarenakan kinerja dari tiap mesin yang berbeda, penyebabnya yaitu depresiasi dari faktor usia, untuk mencegahnya dapat dilakukan dengan cara maintenance. Namun tindakan preventif maintenance tidak dapat berjalan sesuai jadwal, dikarenakan apabila dilakukan maintenance maka kegiatan produksi akan berhenti dan menyebabkan tidak tercapainya target produksi sehingga mengakibatkan hilangnya profit perusahaan. Pengapian yang bervariasi ini akan menyebabkan kadar air pada produk wafer stick tidak sesuai dengan standar yang ditetapkan.

Berdasarkan permasalahan yang diketahui dapat diberikan solusi untuk mengurangi presentase kadar air pada produk wafer stick yang berada diluar batas standar perusahaan. Berhubungan dengan faktor manusia yaitu kurangnya pengecekan dan maintenance kompresor, dapat diperbaiki dengan memasukkan kompresor sebagai objek maintenance tidak hanya pada mesin baking saja, karena kompresor juga sangat berpengaruh pada output produk, terutama pada faktor kadar air. Selain itu 
dapat melakukan pengecekan kinerja kompresor saat awal memulai kegiatan produksi.

Sedangkan hal yang berkaitan dengan metode yaitu pengaturan pengapian yang tidak optimal pada mesin baking dikarenakan kinerja mesin yang bervariasi akibat maintenance tidak sesuai jadwal. Solusi yang dapat diberikan yaitu dengan melakukan penjadwalan ulang maintenance dengan interval waktu se-optimal mungkin agar tidak terlalu pendek jangka intervalnya. Kemudian target profit yang hilang dapat dikejar dengan dilakukan penambahan waktu produksi misalnya dengan dilakukan lembur pada karyawan. Sehingga mesin tetap dalam kondisi prima dan hasil defect output akan berkurang.

\section{KESIMPULAN DAN SARAN}

Terdapat beberapa kesimpulan yang bisa diambil pada penelitian ini. Kesimpulan pertama adalah pada peta kendali rata-rata (X) dan jarak (R) kadar air produk wafer stick yang diambil dapat diketahui terdapat data yang berada diluar batas standar selama bulan Februari 2017. Data ke 11 pada peta kendali rata-rata yaitu data tanggal 13 Februari 2017 memiliki presentase kadar air sebesar 2,185\%.

Kesimpulan kedua, berdasarkan analisis diagram tulang ikan yang memiliki 5 faktor yaitu manusia, mesin, material, metode dan lingkungan, didapatkan 2 aspek yang sangat mempengaruhi presentase kandungan air produk, yaitu faktor mesin dan metode. Pada faktor mesin terdapat permasalahan kompresor yang tidak bekerja dengan normal, sedangkan pada faktor metode terdapat permasalahan pengapian yang tidak optimal. Kompresor tidak bekerja normal disebabkan saluran yang tersumbat, sehingga dapat diketahui akar penyebabnya yaitu kurangnya pengecekan dan maintenance pada kompresor. Selain itu, setting pengapian mesin tidak optimal disebabkan oleh kinerja mesin yang bervariasi akibat depresiasi sehingga dapat diketahui.

Terakhir, rekomendasi perbaikan yang dapat diberikan untuk mengurangi persentase kandungan kadar air pro produk wafer stick yang berada diluar standar adalah dengan memasukkan kompresor sebagai objek pengecekan dan maintenance rutin agar penurunan kinerja dapat dihindari. Kemudian dengan melakukan penjadwalan ulang maintenance dengan interval seoptimal mungkin serta menambahkan waktu kerja misalnya lembur pada karyawan setelah maintenance dilakukan agar dapat mengejar target profit yang hilang akibat berhentinya produksi. Dengan kedua rekomendasi perbaikan tersebut diharapkan akan mengurangi dari defect produk produk wafer stick akibat kadar air yang tidak sesuai standar.

\section{UCAPAN TERIMA KASIH}

Terima kasih disampaikan kepada Laboratorium Statistik dan Rekayasa Kualitas, serta Jurusan Teknik Industri dan Fakultas Teknik Universitas Brawijaya atas segala bentuk dukungan yang telah diberikan.

\section{DAFTAR PUSTAKA}

[1]. Prawirosentono, S. 2007. Filosofi Baru Tentang Mutu Terpadu, Edisi 2. Jakarta: Bumi Aksara.

[2]. Assauri, S. 1999. Manajemen Produksi dan Operasi. Jakarta: Lembaga Penerbit Fakultas Ekonomi Universitas Indonesia.

[3]. Wignjosoebroto, S. 2003. Pengantar Teknik \& Manajemen Industri. Surabaya: Penerbit Guna Widya.

[4]. Gaspersz, V. 2014. Total Quality Management. Jakarta: PT. Gramedia Pustaka Utama.

[5]. Gasperz, V. 2002. Metode Analisa untuk Peningkatan Kualitas. Jakarta: Penerbit Gramedia Pustaka Utama.

[6]. Ryan, T. 2011. Statistical Method for Quality Improvement. Canada: John Wiley \& Sons.

[7]. Heizer, J., dan Render, B. 2005. Manajemen Operasi, Edisi 7. Jakarta: Salemba Empat.

[8]. Ariani, D.W. 2004. Pengendalian Kualitas Statistik (Pendekatan Kuantitatif Dalam Manajemen Kualitas). Yogyakarta: Penerbit Andi.

[9]. Oakland, J. 2008. Statistical Process Control, Sixth Edition. Cornwall: MPG Books Limited, Bodmin.

[10]. Montgomery, D. C. 2009. Introduction to Statistical quality Control, $6^{\text {th }}$ Edition. New York: John wiley \& Sons, Inc.

[11].Andriani, D.P., Rizky, D.A., dan Setiaji, U., "Pengendalian Kualitas Kadar Air Produk Kerupuk Udang Berbasis SNI Menggunakan Statistical 
Quality Control Method", dalam Seminar dan Konferensi Nasional IDEC 2017, Jurusan Teknik Industri, UNS, pp. 98- 107, 8-9 Mei 2017.

[12].Purnomo, H. 2004. Pengendalian Kualitas Statistik. Yogyakarta: Penerbit Graha Ilmu

[13].Gejdoš, P. 2015. Continuous Quality Improvement by Statistical Process Control. Procedia Economics and Finance 34, pp. 565-572.

[14].Andriani, D.P., Rahmatika, F., da Susanto, [16].
M. 2018. Upaya Sustainabilitas UKM Susu Melalui Pengendalian Kualitas Kandungan Kadar Lemak Susu Menggunakan Statistical Quality Control Method. Industri Inovatif Jurnal Teknik Industri ITN Malang, Vol. 8, No. 1, pp. 1-8.

[15].Ishikawa, K. 1985. What Is Total Quality Control? The Japanese Way, 1st Ed. New Jersey: Prentice Hall. 